\title{
CILICIA: \\ THE First Christian CHURCHES IN ANATOLIA ${ }^{1}$
}

\author{
Mark Wilson
}

\begin{abstract}
Summary
This article explores the origin of the Christian church in Anatolia. While individual believers undoubtedly entered Anatolia during the 30s after the day of Pentecost (Acts 2:9-10), the book of Acts suggests that it was not until the following decade that the first church was organized. For it was at Antioch, the capital of the Roman province of Syria, that the first Christians appeared (Acts 11:20-26). Yet two obscure references in Acts point to the organization of churches in Cilicia at an earlier date. Among the addressees of the letter drafted by the Jerusalem council were the churches in Cilicia (Acts 15:23). Later Paul visited these same churches at the beginning of his second ministry journey (Acts 15:41). Paul's relationship to these churches points to this apostle as their founder. Since his home was the Cilician city of Tarsus, to which he returned after his conversion (Gal. 1:21; Acts 9:30), Paul was apparently active in church planting during his so-called 'silent years'. The core of these churches undoubtedly consisted of Diaspora Jews who, like Paul's family, lived in the region. Jews from Cilicia were members of a Synagogue of the Freedmen in Jerusalem, to which Paul was associated during his time in Jerusalem (Acts 6:9). Antiochus IV (175-164 BC) hellenized and urbanized Cilicia during his reign; the Romans around 39 BC added Cilicia Pedias to the province of Syria. Four cities along with Tarsus, located along or near the Pilgrim Road that transects Anatolia, constitute the most likely sites for the Cilician churches. The evidence, though incomplete, points to Cilicia as the location of the first Christian churches in Anatolia.
\end{abstract}

1 Thanks are given to Dr Mehmet Taşlıalan, former director of the Yalvaç Museum and convener of the Second International Symposium on Pisidian Antioch held in Turkey in July 2000, where an initial draft of this article was first presented. 


\section{Introduction}

The book of Acts points to two Antiochs - Antioch on the Orontes and Pisidian Antioch - as important hubs for the growth of the church. Yet there are intimations in Acts and Galatians that Cilicia might be the true birthplace of the Anatolian church. Jews from Anatolia were among the Diaspora pilgrims in Jerusalem on the Day of Pentecost when the Holy Spirit was poured out and the Christian church was born. ${ }^{2}$ Five Anatolian provinces and regions are mentioned in Acts 2:9-10: Cappadocia, Pontus, Asia, Phrygia, and Pamphylia. The presence of Jews in these places is well attested, particularly in the writings of Cicero, Philo, and Josephus. ${ }^{3}$ In fact, of the five million Jews living in the first century, approximately one million are estimated to have lived in Anatolia. ${ }^{4}$ Jews from Anatolia may well have been among the three thousand who responded to Peter's message that day (Acts 2:41). These first believers would return home as individuals who remained active in their local synagogues (cf. Acts 9:2).

\section{Paul's Early Years}

Acts 6:9 mentions another group of Jews from Cilicia and Asia in Jerusalem. They were part of a Synagogue of the Freedmen composed of Diaspora Jews who remained long term in the Jewish capital. Paul, 'a Jew, from Tarsus of Cilicia'5 (Acts 21:39; cf. 22:2) was affiliated with this synagogue. It undoubtedly included friends and relatives from his home region. ${ }^{6}$ This synagogue was responsible for

2 Paul Trebilco in Jewish Communities in Asia Minor (Cambridge: CUP, 1991), 25 , argues that these were probably not pilgrims because they are described as

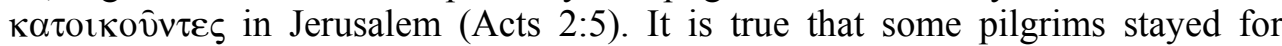
extended periods in Jerusalem as is suggested by existence of the Synagogue of the Freedmen (Acts 6:9). However, the substantival use of same participle in 6:9 ('residents'; NIV, NRSV) suggests that the nations listed next were the true home of the audience. Probably representatives of both groups heard Peter deliver his message (cf. Acts 2:14). Absent from the places listed are Syria and Cilicia.

3 See Trebilco, Jewish Communities, pp. 5-20, for an excellent discussion of the relevant texts.

4 P.W. van der Horst quoted in Trebilco, Jewish Communities, p. 193 n. 11.

5 All Scripture quotations are from the New International Version unless otherwise noted.

6 W.M. Ramsay, The Cities of St. Paul (New York: Doran, 1907), 177-78,

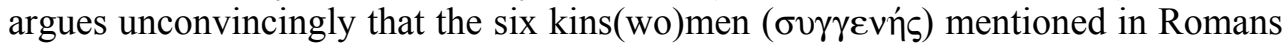
16:7, 11, 21 were not simply Jews but fellow citizens in the tribe of Jews in Tarsus. For Ramsay this constitutes a direct proof that 'there was in Tarsus a body of Jewish citizens' (p. 177). Peter Lampe, 'The Roman Christians of Romans 16', in The Romans Debate (ed. Karl P. Donfried; rev. ed.; Peabody, MA: Hendrickson, 
instigating the persecution of Stephen (Acts 6:11-14). Paul's complicity in Stephen's martyrdom (Acts 7:58; 8:1) launched his career as a persecutor (1 Cor. 15:9) - one abruptly terminated on the road to Damascus (Acts 9:1-18).

Following his conversion, Paul debated with these same Hellenistic Jews who now viewed their young Pharisaic kinsman as a traitor (9:29). ${ }^{7}$ When these Anatolian Jews tried to kill Paul, the Jerusalem church quickly dispatched Paul to Tarsus from Caesarea, Judaea's main port (9:30). Bruce states that Paul 'probably went from Caesarea to Tarsus by sea'. ${ }^{8}$ In Paul's own account of this period, after a fifteen-day visit with Peter and James in Jerusalem, 'Then I went into the regions ( $\kappa \lambda i \mu \alpha \tau \alpha^{9}$ ) of Syria and Cilicia' (Gal. 1:21 NRSV). Although Paul here fails to mention any persecution from the Hellenistic Jews, he does note the local believers heard that he was 'now preaching the faith he once tried to destroy' (Gal. 1:23). This preaching brought swift opposition and deportation. At Caesarea, the capital of Roman Judaea, a ship to Seleucia Pieria, the port of Syria's capital Antioch, was probably more available than a direct passage to Tarsus. At Seleucia he could travel overland to Cilicia or transship to Tarsus, which was connected to the Mediterranean by the Cydnus and a lagoon called Rhegma. ${ }^{10}$ Riesner suggests a further prophetic purpose for Paul's return to Tarsus: 'The first geographical goal of the eschatological mission mentioned in Isaiah 66:19 is Tarshish, which during the New Testament period was identified with Tarsus in Cilicia....[W]e cannot preclude the possibility that Paul ascribed special significance to the fact that his own place of birth (Acts 22:3) was mentioned in this prophetic oracle.'11 Therefore, for Paul to begin his ministry in Tarsus was to fulfill Isaiah's prophecy.

1991), 224-25, instead sees the true significance of the only four uses (cf. also 9:3)

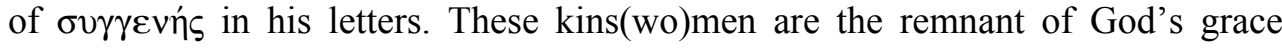
toward Israel. So Paul 'has a special interest in emphasizing the Jewish origin of Christians' and 'in emphasizing the Jewish kinship of Christians in Rome'.

7 That the groups are the same is reinforced through the use of $\sigma \nu \zeta \eta \tau \dot{\varepsilon} \omega$ (Acts $6: 9 ; 9: 29)$, the only two uses of this verb in Acts.

8 F.F. Bruce, The Acts of the Apostles (3rd ed.; Grand Rapids: Eerdmans, 1990), 244.

9 Contra W.M. Ramsay, Historical Commentary on Galatians (London: Hodder \& Stoughton, 1899; Grand Rapids: Kregel, 1997), 46, к $\lambda i \mu \alpha \tau \alpha$ appears to have no technical force here; see F.F. Bruce, Commentary on Galatians (Grand Rapids: Eerdmans, 1982), 102-103.

10 Strabo, Geogr. 14.5.10. In 41 BC Cleopatra sailed up the Cydnus to Tarsus on a barge to hold her famous rendezvous with Antony (Plutarch, Ant. 26; Appian, Bell. Civ. 5.8, 11; Cassius Dio 48.24.2).

11 Rainer Riesner, Paul's Early Period (Grand Rapids: Eerdmans, 1950), 265. 
In Galatians, Paul's own chronology of his ministry is synchronized around his trips to Jerusalem, which occurred 'after three years' and 'after fourteen years' following his conversion (Gal. $1: 18 ; 2: 1 \mathrm{NRSV}$ ). Thus over a decade elapsed between these visits. The terminus a quo for the first Jerusalem visit is placed by Ramsay at AD 32-33 while Jewett puts it at AD 37.12 The beginning of Paul's Cilician ministry would commence soon after. Early Pauline chronology, with the necessary integration between the Pauline and Lucan accounts of the Jerusalem visits, is a notorious crux interpretum. ${ }^{13}$ Although important, this issue is outside the purview of this paper. There is one geographical point on which both agree: Paul places himself in Cilicia during this period as does Luke. His time ends when Barnabas, who first introduced Paul to the apostles in Jerusalem (Acts 9:27), goes to Tarsus to find Paul (Acts 11:25). Hengel and Schwemer estimate that Paul spent at least three and perhaps even four years in Cilicia; I would suggest a five-year stay at a minimum. ${ }^{14}$ Apparently Barnabas had maintained contact through the intervening years. The rare Lucan use of $\dot{\alpha} v \alpha \zeta \eta \tau \dot{\varepsilon} \omega$ here suggests that Barnabas had difficulty finding Paul. ${ }^{15}$ Paul's so-called 'silent years' were busy and not at all a passive spiritual retreat in Tarsus.

\section{Luke's Methodology}

The establishment of the Cilician churches is never specifically mentioned in Acts. This is not unusual since Luke does not mention the origin of the Damascus church either (Acts 9:2). Hengel and Schwemer argue convincingly that Luke so took it for granted that Paul evangelized in Cilicia 'he did not feel it necessary to mention the

12 W.M. Ramsay, St. Paul The Traveler and Roman Citizen (15th ed., London: Hodder \& Stoughton, 1925; Grand Rapids: Kregel, 2001), p. 48; Robert Jewett, Dating Paul's Life (London: SCM, 1970), 100. Ramsay dates the crucifixion of Jesus to AD 30, Jewett to AD 33.

13 For a recent discussion of this problem, see L.C.A. Alexander, 'Chronology of Paul', DPL, pp. 115-23. My position is that Paul's second visit to Jerusalem was the famine relief visit of Acts 11:27-29 and not the visit recorded in Acts 15. The book of Galatians would therefore have been written before the council in Jerusalem.

14 Hengel and Schwemer, Paul, p. 174; Ramsay, St. Paul Traveler, p. 53, dates Barnabas' trip to Tarsus in the early months of AD 43, thus putting Paul in Cilicia for almost a decade.

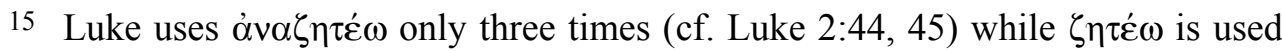
thirty-six times. According to Moulton and Milligan, The Vocabulary of the Greek

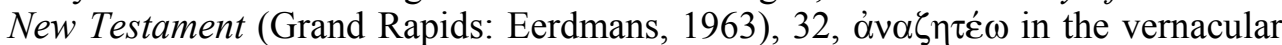
papyri 'is specially used of searching for human beings, with an implication of difficulty, as in the NT passages.' 
fact'. ${ }^{16}$ They further suggest that the Lord's words to Paul in a vision at the temple during his first post-conversion visit, 'I will send you far away to the Gentiles' (Acts 22:21), should be seen as realized when the Jerusalem brothers shortly thereafter took him down to Jerusalem and 'sent him off to Tarsus' (9:30). 'By the use of ' $\xi \alpha \alpha \sigma o \sigma \tau \dot{\varepsilon} \lambda \lambda \varepsilon \imath v$ in these two apparently contradictory events - though for him in substance they belong together - Luke indicates that the sending "far away to the Gentiles" began with the journey to Tarsus.' 17 In Acts, Paul's Cilician ministry is assumed to have occurred in the indefinite lengthy interval between Acts 9:30 and 11:25. Even as Luke fails to include every detail for each outpouring of the Holy Spirit in Acts, Luke here too 'wanted to have readers who sometimes could also read between the lines'. ${ }^{18}$

Another reason relates to Luke's programmatic methodology articulated in Acts 1:8: Jerusalem, Judaea, Samaria, and the ends of the earth, that is, a trajectory outward from Jerusalem. The gospel's advances to Edessa (Urfa) or to north African cities like Alexandria or Cyrene are therefore never mentioned. Luke's expanding spiral is both ethnocentric (Jews, then Gentiles) and geo-politicocentric (Jerusalem to Roman centres in the northeastern Mediterranean). That is why Antioch on the Orontes becomes the next centre of Luke's attention rather than the cities of Cilicia. For Luke, establishing Antioch as a centre of early Christianity is important because it was the capital of the Roman province of Syria and the third largest city in the Roman Empire. Paul is sent from and returns to this 'mother' church on each of his ministry journeys except his final one when he is imprisoned in Judaea. A personal reason for the attention given to Antioch might also be involved: church tradition suggests that the city was Luke's home (Eusebius, Hist. Eccl. 3.4.6). ${ }^{19}$

\footnotetext{
16 Martin Hengel and Anna Maria Schwemer, Paul Between Damascus and Antioch: The Unknown Years (Louisville: Westminster John Knox, 1997), 155.

17 Hengel and Schwemer, Paul Between Damascus and Antioch, pp. 155-56.

18 Hengel and Schwemer, Paul Between Damascus and Antioch, p. 156.

19 But see Ramsay, St. Paul Traveler, pp. 162-63; 302, 304, who argues Luke

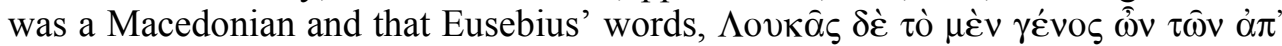

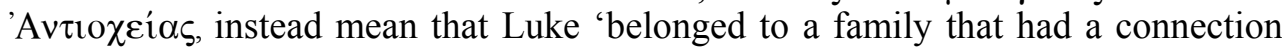
with Antioch.'
} 


\section{The Mention of a Cilician Church}

Acts 11:26 describes how Barnabas brought Paul from Tarsus to Antioch. ${ }^{20}$ For over a year the two taught a group of disciples there who became known as Christians. After a trip to Jerusalem for the famine relief visit (Acts 11:27-30; 12:25), Barnabas and Saul are sent out by the Antiochian church on a ministry journey that begins in Cyprus but concentrates mainly on Pisidian Antioch and three other south Galatian cities (Acts 13:1-14:28). Luke next recounts the important Jerusalem council where the question of circumcision of Gentiles is decided and instructions facilitating table fellowship between the Jewish and Gentile believers are given (Acts 15:1-21). The decision of the council is addressed to the Christians in the churches in Antioch, Syria, and Cilicia ${ }^{21}$ (Acts 15:23). The order of the addressees follows the geographical order by which a messenger would deliver the letter from Jerusalem - first to Antioch, then to the next major Syrian city, probably Alexandria ad Issum, and finally to Cilicia. This is the first mention of a church in Cilicia.

After an extended period of further ministry in Antioch, Paul decides to revisit the south Galatian churches. But when Barnabas wishes to take along again his cousin, John Mark, who deserted the pair in Perga, the two have a sharp disagreement and Paul instead takes Silas (Acts 15:36-40). The second journey commences with the two passing through Syria and Cilicia (Acts 15:41) while on their way to Derbe and Lystra. This is the second mention in this chapter of a church in Cilicia.

\section{Paul's Cilician Ministry}

Two questions naturally follow: who established these churches in Cilicia and where were they located? Tarsus was Paul's birthplace; indeed Jesus, in his instructions to Ananias following Paul's conversion, identifies him as 'a man from Tarsus' (Acts 9:11). Paul's connection with Tarsus has recently been challenged by Wallace and Williams who argue that, since ancient civic citizenship passed

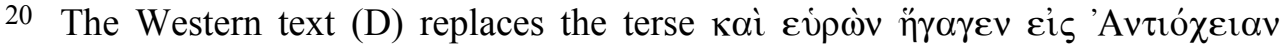

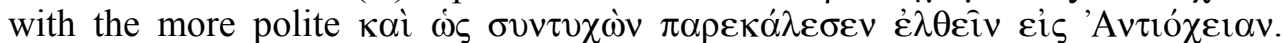
According to Hengel and Schwemer, Paul, p. 179, 'Barnabas does not simply take Paul to Antioch, but asks him to come there with him.'

21 While the lack of the article here and in some manuscripts of 15:41 suggests that the political configuration of the double province is to be understood (cf. 1:8; see Riesner, Paul's Early Period, 266), the geographical element is certainly present in 15:41 (cf. 8:5ff.) and in Galatians 1:21.
} 
through descent and not domicile, Paul 'need ever [sic] have visited the city, much less lived there'. They conclude that attempts to develop a formative Tarsian context for Paul's adolescence 'are built on insecure foundations'. ${ }^{22}$ The Seleucid ruler Antiochus IV settled Jews in Cilicia in $171 \mathrm{BC},{ }^{23}$ and his family perhaps received Greek citizenship at that time. Rapske rightly rejects an interpretation of $\pi$ o $\lambda$ i $\tau$ ' in Acts 21:39 as domicile only, asserting that '[T] fact recording Paul's claim to a legally valid Tarsian citizenship.'24 An epitaph found in Jaffa mentions a Judas, who is a son of Joses and

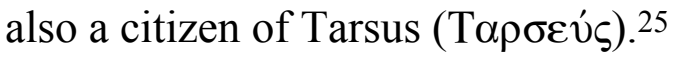

The presence of Jews in Cilicia is affirmed by Agrippa I in his letter to Caligula (Philo, Leg. 281). The epigraphical evidence for Jews in Tarsus and Cilicia Pedias is scanty because of the difficulty in excavating population centres. However, the significant amount of Jewish or Judaizing epigraphic evidence from Cilicia Tracheia suggests to Hengel and Schwemer that 'the Jewish population of Tarsus and other Cilician cities must have been considerable.' 26 A lead coffin, dating from late Antiquity and reportedly from Elaiussa Sebaste (Ayaş) in Tracheia, is decorated with four menoroth in relief. 27 Remains of a building found in Mopsuestia (Misis), with a Samson and a Noah's Ark mosaic and dating to the fifth century AD, have been positively identified by Hachlili as synagogue. ${ }^{28}$ Although this evidence dates later than the biblical period, it may point to a long-standing Jewish community. 29

Paul was likewise born a Roman citizen (Acts 22:25, 28). While the particulars of his family's acquisition of citizenship are unknown, several possible scenarios have been conjectured. Murphy-O'Connor

\footnotetext{
22 Richard Wallace and Wynne Williams, The Three Worlds of Paul of Tarsus (New York: Routledge, 1998), 180.

23 Ramsay, Cities, pp. 169-86, provides the classic discussion of the subject.

24 Brian Rapske, Paul in Roman Custody (vol. 3 of The Book of Acts in Its First Century Setting; ed. Bruce W. Winter; Grand Rapids: Eerdmans, 1994), 76.

$25 C I J$ II, no. 925; cf. Hengel and Schwemer, Paul, pp. 160, 415-16 n. 821.

26 Hengel and Schwemer, Paul, p. 161. See their review of the evidence on pp. 161-67.

27 Rachel Hachlili, Ancient Jewish Art and Archaeology in the Diaspora (Leiden: Brill: 1998), 291. This coffin is now displayed outside at the Adana Museum.

28 Hachlili, Ancient Jewish Art, pp. 213-16; ABD, 6:261. Other scholars, however, have instead identified it as a Christian church; cf. S. Hill, The Early Byzantine Churches of Cilicia and Isauria (Brookfield, VT: Variorum, 1996), 236.

29 The third-century synagogue at Sardis likewise represented a long-standing Jewish community that was present in the first century (Obad. 20; Josephus, Ant. 12.149).
} 
suggests, 'The simplest possibility...is that Paul's father had been a slave who was set free by a Roman citizen of Tarsus, and who thereby acquired a degree of Roman citizenship which improved with each succeeding generation.' 30 If Paul's family were settled in Tarsus by Antiochus IV and free citizens of the city, it is problematic to speculate that they were slaves. A better solution is that citizenship was granted by the Romans sometime in the mid first century BC. The competition for support after 49 BC elicited generous offers of individual freedom in Cilicia from Pompey, Caesar, and Antony, all of whom had personal relations with Tarsus. When Cicero was proconsul of Cilicia (51-50 BC), citizens were so numerous in Cilicia that he could hold a levy (Att. 5.18). In the Augustan period a conventus of Roman residents existed at Mallus. ${ }^{31}$ Thus citizenship was granted by one of these Roman leaders in return for services rendered to his cause. ${ }^{32}$

During this period Luke assumes that 'Paul now remains quietly for a while in his hometown of Tarsus', according to Haenchen. ${ }^{33}$ 'Quietly' is a relative term because Paul soon became very busy. To

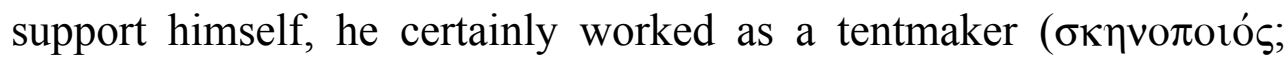
Acts 18:3). Perhaps he learned this trade as a youth in a family business or later as a rabbi-in-training in Jerusalem. A material with which he was surely familiar was the rough cloth made of goats' hair called Cilicium, named after his native province. ${ }^{34}$ During his formal training as a Pharisee in Jerusalem, the Hebrew text was his primary Scripture (Acts 22:3). Although he maintained relationships with the Hellenist Jews there, Riesner observes that in Tarsus, ' $[\mathrm{H}] \mathrm{e}$ doubtless deepened his knowledge of the Greek translation along with its recensions.' 35 He also probably deepened his knowledge of Greek

\footnotetext{
30 Jerome Murphy-O'Connor, Paul: A Critical Life (Oxford: OUP, 1997), 41. This opinion is shared by Wallace and Williams in The Three Worlds of Paul of Tarsus, pp. 140-42.

31 T.R.S. Broughton, 'Roman Asia Minor', in An Economic Survey of Ancient Rome (ed. Tenney Frank; Baltimore: Johns Hopkins, 1933), 4:547.

32 Letters of Octavian (IGLS III 1:718) concerning Seleucus of Rhosus provide an illustrative parallel. Dating between 42 and $30 \mathrm{BC}$, they are written to the city of Rhosus, with copies to be deposited in the archives of Tarsus and Antioch. Octavian granted Roman citizenship to Seleucus and his family for the naval aid Seleucus had bravely provided Rome. See Robert Sherk, Roman Documents in the Greek East (Baltimore: Johns Hopkins University Press, 1969), 299-301.

33 E. Haenchen, The Acts of the Apostles (Philadelphia: Westminster, 1971), 333.

34 P.W. Barnett, 'Tentmaking', DPL, pp. 925-27; cf. David Magie, Roman Rule in Asia Minor (Princeton: Princeton University Press, 1950), 1:272.

35 Riesner, Paul's Early Period, 268.
} 
literature and thought, a background with which he would have limited exposure growing up in Jerusalem. ${ }^{36}$ Knowing of his future mission to the Gentiles (Acts 9:15; Gal. 2:7), perhaps he partook of the philosophical teaching of which Tarsus was renowned. ${ }^{37}$ Yet, despite residing in such an atmosphere of learning, Paul later denies any formal rhetorical training (2 Cor. 11:6). ${ }^{38}$ Spiritually, this period must have been a time of deepening reflection and understanding, which followed his whirlwind conversion and first flush at evangelism in Arabia and Judaea. The application of grace through the Holy Spirit in contrast to his training in the law would indeed be a maturing process. The autobiographical 'I' section of Romans 7 might well have been experienced now. As Dunn keenly notes, 'There is an existential character throughout the whole section ( $\mathrm{vv} 7-25)$, and it is difficult to believe that Paul is not speaking at least to some extent out of his own experience.' 39 His experience of being taken up to the third heaven (2 Cor. 12:1-6), dated to fourteen years prior to writing 2 Corinthians from Macedonia around 56, clearly occurred during his time in Cilicia.

Finally, Paul now began evangelizing Tarsus and surrounding Cilicia. Indirect evidence for such ministry is found in 2 Corinthians 11:23-29 where Paul lists a series of trials, some of which are never or only partially mentioned by Luke in Acts. Verse 24 is particularly suggestive: 'Five times I received from the Jews the forty lashes minus one.' The reception of thirty-nine lashes suggests an early period when Paul still submitted to synagogue discipline. The synagogue was still Paul's religious home in the Diaspora and the starting point for his ministry in each city. Until he withdrew from the synagogue, he was required to submit to its discipline lest he deny his Jewishness. Bruce writes, 'It may well be that some of his experiences of the thirty-nine lashes belong to this Cilician phase of his life.' 40 Riesner likewise presumes that other persecutions and tribulations

36 Murphy-O'Connor, Paul, 48, however, notes that even in Jerusalem Homer and other Greek literature was read in Pharisaic circles.

37 Strabo, Geogr., 14.5.13 writes, 'The people at Tarsus have devoted themselves so eagerly, not only to philosophy, but also to the whole round of education in general, that they have surpassed Athens, Alexandria, or any other place that can be named where there have been schools and lectures of philosophers....Further, the city of Tarsus has all kinds of schools of rhetoric.'

38 Hengel and Schwemer, Paul, 171, issue a well-advised caution: 'The significance of the rhetoric of the schools on Paul is much exaggerated today, following a fashionable trend.'

39 James D.G. Dunn, Romans 1-8 (Dallas: Word, 1988), 382.

40 Bruce, Paul, 128. 
listed in 2 Corinthians 11 'derive from the period during which Paul missioned from his base in Tarsus.' ${ }^{11} \mathrm{He}$ evidently met with success during this period of ministry because when he returned later with

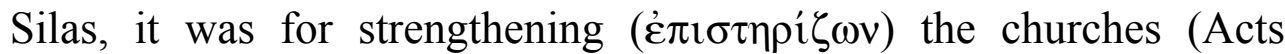
15:41). Paul only returned to 'strengthen' disciples in places where they had been evangelized and instructed, as with the Galatian churches (Acts 14:22; 18:23).

Osborne cites two pieces of evidence to support a Cilician ministry. First, '[T] he fact that Paul was accepted so readily by the congregation at Antioch indicates that his curriculum vitae was well known to them.' And second, 'Gal 2:2 where Paul refers to "the gospel which I am accustomed to preach to the Gentiles" ... must refer to the gospel which he preached before his missionary programme as recorded by Luke began.' Osborne argues that Paul's

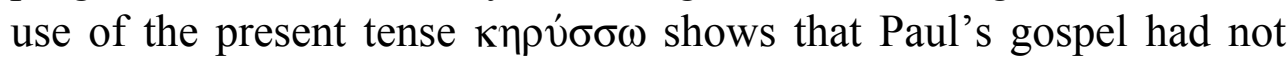

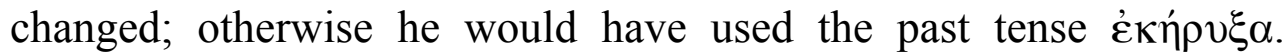
While it is precarious to sustain the existence of a Pauline mission based on a tense change alone, the cumulative evidence points to Osborne's conclusion. 'We may therefore say with some assurance that Paul was carrying on evangelistic work in Syria and Cilicia for some eight years before he came to Antioch to head up the gentile mission.' 42

\section{The Geography and Road System of Cilicia}

The origin of the Greek word Ki $\lambda \imath$ ki $\alpha$ is uncertain. In the ninth century BC the Assyrians called the Taurus foothills Khilakku and the plain below Que. Greek references to Cilicia and Cilicians (Cilices) also begin about the same time (e.g. Iliad 6.397). Located on the northeastern corner of the Mediterranean Sea, Cilicia was divided into two regions - Rough (Gk. Tracheia; Lat. Aspera) and Smooth (Gk. Pedias; Lat. Campestris). Because only the latter region is germane to our study, our comments will focus on it. Pedias consists of three distinct areas — the ancient Aleian Plain (Çukurova), a northeastern plain (Yukarı Ova), and a coastal strip along the Amanus Mountains (Nur Dağları). The Aleian Plain is drained by three important rivers - the Cydnus (Tarsus Çay) whose source is high in the Taurus and the Sarus (Seyhan Nehri) and the Pyramus (Ceyhan Nehri) which rise

41 Riesner, Paul's Early Period, 267. He also inquires whether a Cappadocian mission might also have occurred during this period but dismisses the possibility (pp. 267-68).

42 Robert E. Osborne, 'St. Paul's Silent Years', JBL 84 (1965) 60. 
far to the north in the mountains of Cappadocia. The northeastern plain is separated from the Aleian Plain by a limestone ridge running south from the Taurus that meets the Amanus. Only the narrow gorge of the Pyramus at Mopsuestia (Yakapinar) provides a passage between the two plains. ${ }^{43}$

Entrance to Cilicia from the north came through the Taurus Mountains at the Cilician Gates along the Pilgrim's Road that crossed Anatolia from northwest to southeast. An important junction at Tarsus joined the Pilgrim's Road with the coastal road running westward to Soli and Tracheia. At Mopsuestia travelers encountered another junction. Those journeying eastward took the northern branch past the Amanian Gates (Toprakkale), where a short spur led north to Hieropolis Castabala, then continued to Zeugma, Rome's border station on the Euphrates. ${ }^{44}$ Those heading to Syria took the shorter southerly route past Epiphania that reached the coast above Issus. ${ }^{45} \mathrm{~A}$ short leg connected the Amanian Gates with the coast for travelers coming from the east. The main road followed the coast southward past Issus and Baiae where it passed through the Cilician-Syrian Gates. This spur of the Amanus Mountains formed a natural boundary between Cilicia and Syria (Cicero, Fam. 2.10.2; 15.4.4; Att. 5.20.3; Strabo Geogr. 14.5.19 [676]). Alexandria was situated a short distance further south on the coast before the road climbed southeastward over the Syrian Gates (Belen Geçiti) to Antioch. ${ }^{46}$

43 This paragraph was largely drawn from M.V. Seton-Williams, 'Cilician Survey', AS 4 (1954) 121-24 and Magie, Roman Rule, 1:271-72.

44 In the Genesis Apocryphon (1QGenAp XXI:16-17) Abraham is depicted as following this route in his circular journey of the Near East.

45 This route is depicted by David French in Roman Roads and Milestones of Asia Minor: The Pilgrim's Road (Ankara: British Institute of Archaeology / Oxford: B.A.R. International, 1981), Map 7.

46 The description of Cilicia's southern boundary is very confusing in the sources. Cicero identifies the Amanus and its watershed as that which divided Syria from Cilicia (Att. 20). Strabo in one place (Geogr. 14.5.1) notes that Issus is the limit of Pedias while in a second (14.5.19-20) includes Rhosus, Myriandrus, and Alexandria in Cilicia and states that Seleucia Pieria is the first Syrian city along the coast. A.H.M. Jones, Cities of the Eastern Roman Provinces (2nd ed.; Oxford: Clarendon, 1971), 200, includes Rhosus and Alexandria in Pedias, while Magie, Roman Rule, 2.288 n. 31, locates Rhosus in northern Syria. Luke seems to indicate the boundary was above Alexandria, where it was fixed when Vespasian separated Cilicia from Syria in AD 72. 


\section{The Roman History of Cilicia ${ }^{47}$}

The two Cilicias, as Levick notes, were not 'for nearly forty years...included in the Roman province to which they had given their name.' 48 This original province Cilicia was organized in $102 \mathrm{BC}$ as the second Roman province in Anatolia. Pedias was finally attached to Cilicia in $67 \mathrm{BC}$ after Pompey defeated the pirates. Dio Chrysostom (Or. 34.7-8) declares that Tarsus became the capital of the province at this time (c. $64 \mathrm{BC}$ ). However, the province's status was diminishing, as evidenced by the fact that Cicero was its last governor of consular rank. As early as 39 BC Pedias was added to the province Syria and that affiliation was apparently continued in the early principate. ${ }^{49}$ For example, Tibullus connects the Cilicians, the Cydnus River, and the Taurus in his elegy to his patron M. Valerius Messalla Corinus who served as proconsul of Syria around 31 BC. 50 During Paul's lifetime Pedias was therefore part of the province of Syria. This arrangement continued until AD 72 when Vespasian finally made Pedias its own province with Tracheia. Broughton puts the size of this new province at 13,945 square miles and estimates its population at 900,000 with the majority inhabiting Pedias. ${ }^{51}$

\section{The Cities of Cilicia}

After Alexander captured the Cilician Gates and then defeated Darius III in 333 BC at Issus, the hellenization of Cilicia occurred rapidly. Following Alexander's death the Seleucids controlled Pedias continuously except a period when the Ptolemies held Soli and Zephyrium. Under Seleucus Nicator (312-281 BC) and Antiochus IV (175-164 BC), in particular, the Seleucids pursued a policy of urbanization and hellenization at the following cities: Tarsus (Antiochia on Cydnus), Mopsuestia (Seleucia on Pyramus), Aegae,

\footnotetext{
47 The pre-Christian history of Cilicia is admirably reviewed by M.V. SetonWilliams, 'Cilician Survey', $A S 4$ (1954) 125-45, and of Tarsus in particular by Ramsay, Cities, 85-235.

48 Barbara Levick, Roman Colonies in Southern Asia Minor (Oxford: Clarendon, 1967), 21.

49 This information was drawn from Ronald Syme, 'Observations on the Province of Cilicia', in Anatolian Studies Presented to William Hepburn Buckler (ed. W.M. Calder and Josef Keil; Manchester: Manchester University Press, 1939), 299-300, 304-305, 326-27.

50 'I could sing of the Cydnus, too, whose waves, sky-colored, move slowly,/ imperceptibly, on toward the calm lagoon,/ or of that Asian peak, home of longhaired Cilicians,/ Taurus, whose top can blot out stars and moon' (1.7.13-16).

51 T.R.S. Broughton, 'Roman Asia Minor', 4.815.
} 
Adana (Antiochia on Sarus), Mallus/Magarsus (Antiochia on Pyramus), Oeniandus (Epiphania), and Castabala (Hieropolis), Soli, Mallus, Epiphania, and Adana. ${ }^{52}$ When the Romans assumed control of Pedias in the first century BC, many of its cities were decaying because of the depredations of the pirates and the conquest by the Armenian king Tigranes (83 BC). According to Jones, these cities Pompey 'repopulated with settlers drawn from among the more respectable of his pirate captives'.53 Many of the cities observed their re-foundation from this period 67 to 65 BC. During this reorganization, writes Judge, Pedias 'was apparently divided entirely into the territories of seventeen Republican cities, a mark of its intensely concentrated development'. ${ }^{54}$ It is to these cities a century later that Paul returned with the gospel. ${ }^{55}$

\section{The Cities Paul Evangelized}

While Paul may have attempted to evangelize all seventeen of the Cilician cities, he probably learned the impossibility of doing so. This experience would influence his later evangelism strategy. Six cities emerge as candidates for Pauline churches. ${ }^{56}$ A brief sketch with particular reference to later Christian history is presented next. Three certain cities are Tarsus, Adana, and Mopsuestia, all on the Pilgrim's Road.

Tarsus, the home of Paul, was the capital of the conventus. Strabo (Geogr. 14.5.13), writing during Paul's childhood, stated that the city 'not only has a flourishing population but also is most powerful, thus keeping up the reputation of the mother-city'. Dio Chrysostom (Or. $33.17,28 ; 34.7-8,37)$ called it 'the greatest of the cities of Cilicia'. Tarsus largely disappears from church history until around AD 250 when Dionysius of Alexandria reckons Helenus of Tarsus among the most distinguished bishops of the East (Eusebius, Hist. Eccl. 7.5.4; 7.28.1; cf. 6.46.3). Helenus' role in organizing a synod at Antioch in AD 268 that refuted Paul of Samosata suggests a longstanding authority in the Tarsian bishopric. Hengel and Schwemer reasonably conclude: 'We may assume that after the founding of the community

52 Jones, Cities, 197; J. Daniel Bing, 'Cilicia', ABD, 1:1023-24.

53 Jones, Cities, 202.

54 E.A. Judge, 'Cilicia', ISBE 1:699.

55 A complete discussion of these cities can be found in Jones, Cities, 202-207; Magie, Roman Rule, 1.272-76; 2.1146-52; Michael Grant, A Guide to the Ancient World (New York: Wilson, 1986; repr., New York: Barnes \& Noble, 1997), s.v.

56 Hengel and Schwemer, Paul, 426 n. 892, add Mallus and Magarsus to my list because of the supposed presence of synagogues in these 'larger' cities. 
by Paul there were always Christians in this famous and busy city.' 57 Today the remains of St Paul's Church (newly restored) in Tarsus do not date earlier than the medieval period. ${ }^{58}$

Adana was also an important river crossing, situated on the west bank of the Sarus. Fourteen arches survive of a bridge probably built by Auxentius in the late fourth century. ${ }^{59}$ Cassius Dio (47.31.2) records that Adana and Tarsus had a longstanding rivalry. Many antiquities from Cilicia are housed at the regional museum in Adana.

Mopsuestia was situated on the east bank of the Pyramus River at an important crossing. Mopsuestia's position on the main road brought prosperity. As mentioned earlier, it may have had a Jewish population based on the possible synagogue remains found there. The city's Christian legacy is enshrined through the famous church father Theodore (AD 342-408) who was from the city.

Hieropolis Castabala is a probable site of a church. Its location along Roman roads taking traffic north and east ensured Hieropolis its importance. Castabala was under the rule of the client king Tarcondimotus and his grandson Philopator II until the latter's death in $\mathrm{AD}$ 17. At that time the Romans incorporated his territory into the province of Syria. The city became a Christian bishopric, which is preserved in the remains of two fifth-century churches.

Soli (Soloi)/Pompeiopolis is a possible site of a church. It was located a few miles east of the Lamus River, which served as the western boundary of Pedias. Soli was the home of the poet Aratus (b. 301 BC) who wrote The Phainomena (Strabo, Geogr. 14.5.8). Paul quotes his fellow Cilician poet before the Aeropagite council in Athens (Acts 17:28).

Anavarza is another possible site, although its rivalry with Tarsus, as Ramsay states, was 'an important feature of the later Roman period, the second and following centuries after Christ; but it exercised no appreciable influence in determining the character of the Pauline Tarsus.' 60 However, further comment is required because of a statement made by Mary Gough who, with her husband Michael, did pioneering archaeological survey work in Cilicia in the early 1950s.

57 Hengel and Schwemer, Paul, 157.

58 Levent Zoroğlu, A Guide to Tarsus (Ankara: Dönmez Offset, 1995), 42.

59 Ekrem Akurgal, Ancient Civilizations and Ruins of Turkey (8th ed.; Istanbul: Net, 1993), 345. Restored by Justinian and the Turks, this bridge (Tasköprü) still carries traffic over the river.

60 Ramsay, Cities, 99. 
She wrote regarding the Roman chariot way cut through solid rock at Anavarza:

Indeed, this chariot way was part of the main road to the east, the road that led from Tarsus and Adana through Mopsuestia to the Amanian Gates and onwards to Syria. No one can prove that St. Paul trod it, but unless he made a detour to the south, and preferred the swamps and marshland of the Aleian Plain, it is hard to believe that he did not pass this way.... When St. Paul came to Anavarza he could have bathed in the public baths and sat afterwards in some cool portico. ${ }^{61}$

As we have seen, the main road did not lead through Anavarza and indeed such a loop was quite a detour. Regarding this assertion, David French says, 'Gough was perhaps speculating a little. There is no evidence that Paul went by this road or by that.' 62

\section{Conclusion}

The founding of the Cilician churches during Paul's 'silent years' has several important implications for early Christian history. First, these churches antedate even the establishment of the church in Antioch on the Orontes, which Luke so emphasizes in Acts. A corollary is that they precede the establishment of the churches in south Galatia, particularly Pisidian Antioch, during the first ministry journey. The churches in Cilicia were thus the first Christian churches in Anatolia.

Second, the presence of these churches influenced the itinerary of Paul's first journey. The Mediterranean coast southward was already evangelized (Acts 11:19). Because the boundary of the Roman Empire was just a few miles east of Antioch, evangelization in that direction was ruled out. Because of the existence of the Cilician churches, Paul had no incentive to travel northward. West was the only direction open, and Cyprus became a perfect first stop since it was the home of Barnabas (Acts 4:36). With the conversion at Paphos of the Roman proconsul Sergius Paulus, Paul now leads the apostolic party northward to Anatolia (Acts 13:6ff.). Mitchell slights Luke for failing to spell out the real incentive that carried the mission inland from the coast: 'Sergius Paullus, Paul's most recent and most distinguished convert, was a native of Pisidian Antioch.' ${ }^{63}$ A look at a

61 Mary Gough, Travel into Yesterday (Garden City, NY: Doubleday, 1954), 45.

62 E-mail message to the author, March 28, 2000. French continues, 'As far as I am concerned, the road to the Syrian gates or the Amanus Pass went via Mopsuestia and Issus, i.e. across the "swampy" plain south of Ceyhan. I have been over the ground and there are traces of a Roman road both before and after the massive gate published by the Austrians in the TIB Supplement.'

63 Stephen Mitchell, Anatolia (Oxford: Clarendon, 1993), 2:6. 
map of the region confirms that if the south Galatian cities were Paul's original target, he surely took the long way around. Paul would see this providential encounter and redirection as orchestrated by the Holy Spirit, whom Luke portrays as active in every stage of Paul's ministry journeys (Acts 13:2; 16:6-10; 20:23).

Finally, Paul's approach to church planting used in his three ministry journeys was gained through his experience in Cilicia. He evangelized in key cities along major roads where there was a significant Jewish and Roman population. In these cities he first went to the synagogues where he would be rejected and persecuted. Then he would preach to the Gentiles. Taking a core of Jewish and Gentile believers, Paul would establish a church and appoint local leadership while maintaining contact through personal visits and letters. Using this modus operandus, Paul in two decades successfully established churches throughout Anatolia and Greece, so that he could write from Corinth: '...there is no more place for me to work in these regions' (Rom. 15:23). ${ }^{64}$

64 The challenge for biblical scholars to access the relevant historical and geographical information on Cilicia is considerable. I echo the call by Hengel and Schwemer that " $[\mathrm{t}]$ here is an urgent need for a thorough monograph on ancient Cilicia and its cities' (Paul, 415 n. 814). 